Marquette University

e-Publications@Marquette

Social and Cultural Sciences Faculty Research and

Publications

Social and Cultural Sciences, Department of

$11-1-2008$

Compelling Intimacies: Domesticity, Sexuality, and Agency

Aaron Goodfellow

Johns Hopkins University

Sameena A. Mulla

Marquette University, sameena.mulla@marquette.edu

Accepted version. Home Cultures, Vol. 5, No. 3 (November 2008): 257-269. DOI. (C) 2008 Berg. Used with permission. 


\title{
Compelling Intimacies: Domesticity, Sexuality, and Agency
}

\author{
Aaron Goodfellow \\ Department of Anthropology, Johns Hopkins University \\ Baltimore, $M D$ \\ Sameena Mulla \\ Department of Cultural and Social Sciences, Marquette \\ University \\ Milwaukee, WI
}

\begin{abstract}
This introduction highlights what we call "Compelling Intimacies" the multiple desires, affects and affinities that arise at the intersection of institutions, actors, technologies, and ethical discourses to exert persuasive pressures on subjects. Each article animates different facets of the intensities born of intimacy as they operate across social and relational fields. The authors separate agency from intention in their efforts to identify the vitality of human and non-human relations. Together, the articles demonstrate how domesticities arise through diverse sets of circumstances, emerging in multiple incarnations-often in the same household-in such a way as to generate a wide range of affects and affinities. Finally, each author turns attention to the so called "small events" that come to affirm or deny life as given form in everyday household arrangements, kin relations, friendships, and institutional settings, thereby suggesting the political stakes evoked by differing forms of care.
\end{abstract}

Keywords: domesticity, sexuality, intimacy, affect, affinity

The title, "Compelling Intimacies," refers to the multiple desires, affects, and affinities that arise at the intersection of institutions, actors, technologies, and ethical discourses to exert persuasive

Home Cultures, Vol.5, No. 3(November 2008): pg. 257-269. DOI. This article is (C) Bloomsbury Publishing and permission has been granted for this version to appear in e-Publications@Marquette. Bloomsbury Publishing does not grant permission for this article to be further copied/distributed or hosted elsewhere without the express permission from Bloomsbury Publishing. 
pressures on subjects. The title, we feel, gestures towards the unifying features of the articles found within-these being domesticity, sexuality, and a common concern with the different ways intimacy is born of the complex relations of everyday life. The work of such intimacies remains curious to anthropologists due to the powerful forces they call into being. In the articles that follow, each author animates different facets of intensities born of intimacy, as they operate across social and relational fields. It is here that the authors turn to the question of agency, separating agency from intention, and identifying the vitality and force of human and non-human relations. Together, the articles demonstrate how domesticity arises through diverse sets of circumstances, emerging in multiple incarnations-often in the same household-in such a way as to generate a wide range of affects.

Often interchanged with terms such as "home" and "family," the word "domesticity" often invokes concern with sexual reproduction. The household has oft been described as central to the reproduction of both individuals and the social body. We suggest that particular forms of domesticity are dependent on sexual attachment and transgression, and thus on a range of desires, attachments, and investments given form by particular material and social realities.

The articles emphasize the emergence of differing domesticities-both within a single household and across geopolitical space-and the operations of power that contour these forms of living. By turning attention to the so called "small events" that come to affirm or deny life in households, kin relations, friendships, or institutional settings, the articles suggest the political stakes evoked by differing forms of care. Our attention to the ordinary events of everyday life emphasizes the ways domestic relations are enmeshed within the formidable and subtle regulatory processes of such things as the law, institutional ethical discourses, moral economies, therapeutic practices, and such things as the sense of taboo that infuses intimacy and other forms of affiliation found in household relations. The forms, gestures, and expressions of care, desire, and attachment discussed here are understood to extend between individuals, "things," bodies, kin, strangers, built structures, institutions, machines, political projects, and substances. 
The home and the domestic are often imagined as separate from civil society, as a distinct set of relations separate from the public sphere yet contained within and essential to the politico-jural domain. ${ }^{1}$ Here, attention is focused on processes to show how care is born, sustained, and shaped by unanticipated alliances and actants. How, and in what ways, do everyday interactions come to affirm or invalidate life?

It is often taken for granted that living orients away from death and that an attachment, or a will, to life is normal. Yet scholars such as Canguilhem (1991), Donzelot (1980), Freud (1915), and Foucault (1999) teach that notions of the pathological and of death and dying are entangled in concepts of life, essential to living, and thus interwoven and integral to the operation of the domestic sphere. ${ }^{2}$ Homelessness, abuse, HIV, and the work of structural violence provoke an examination of the intimate relationships between the state, modes of regulation, and the lives and deaths bound to institutional investments in the domestic. ${ }^{3}$

Judith Butler (2000), among others, has productively and provocatively evoked the figure of Antigone to discuss the entanglement of life and death in household relations, kinship, and matters of the state. Butler reveals the ways sexuality and notions about sexual reproduction become central to decisions regarding what Foucault (1999) has called "letting die" and "making live." Antigone is a compelling figure in that her bid to secure her place in a moral order-whether one of kinship or the laws of the state-effects her own death while affirming the life and limits of a particular political project. The articles present a variety of ethnographic scenes located within housing cooperatives, hospital emergency rooms, HIV/AIDS clinics, drug treatment facilities, and homes in Buenos Aires, Argentina, Miami, Florida, and Baltimore, Maryland. The authors show that domesticity hinges on unintentional and often unanticipated alliances that form between persons, words, institutions, technologies, and "things," which often place the body and its future at stake in unforeseen ways. How do institutional commitments to ideas about sexuality and the future promised by appropriate modes of reproduction come to hedge life's chances in household relations?

Each author questions the way domesticity and the domestic sphere come to figure centrally in the (re)production of sociable 
subjects, offering detailed analysis of the ways life and death become folded together-brought into close proximity or placed at a distancethrough ordinary relations. The authors bring attention to the partnering of criminality, violation, and risk with notions of nurturance and care in the building and maintenance of intimacy to illuminate how the state's efforts to ensure its promised future may occlude the known and often accepted failures and violence of its own institutions. How might we begin to take account of the presence of criminality in kinship or the resurgence and tenacity of moral projects in the lives of those whose relations are pictured as pathological because they orient away from life-such as HIV-positive drug addicts, those whose relations are criminal and imagined to be instrumental to the perpetuation of violence and poverty, or children whose households include incest?

Perhaps obviously, the contingencies associated with homelessness, with chemical dependency, with sexual violence and abuse, or HIV transfigure normative moral projects and challenge efforts to portray experience in the clear lines and images provide by dominant notions of kinship, care, or well-being. The efforts, gestures, expressions, words, and vocabularies used to render the contingencies of such forms of living legible demonstrate how the non-domestic is always implicated in the domestic. Das, Ellen, and Leonard describe the relationship between the domestic and the non-domestic as one of contagion, in which the domestic is always "infected by affects that circulate in wider politico-jural domains," indicating the importance of moving away from notions that characterize the domestic in terms of well-defined corporate groups. ${ }^{4}$ Procupez shows how sexual tensions and jealousy are cause for concern and intervention in the activistinitiated housing cooperatives where she works in Buenos Aires. It is not that the world comes to shape the domestic, but rather it is the domestic that overflows the home and seeps into the world.

Rather than approach affect and sensual experience as clearly situated artifacts flowing from a historical telos-as if one might a priori assume the existence of such defining concepts as "community," "population," or "geographical region,"-the authors suggest that it is the state's response to perceived crises that configures experience as general and spatially delineates such things as the legacy of violence, disease, and the failure of the domestic. This perspective allows the 
authors to reveal the densely variegated forms of attachment that become homogenized under such categories as "culture of poverty," "African-American kinship," "victims of violence," "homeless," or "risk group." The following articles suggest it is the all too easy deployment of such formulations that tends to entangle the divergent actors and stakeholders in the domestic at the corporeal level.

Within various domestic milieus, the body is always vulnerable to the suspension or activation of intimacy and care. Goodfellow and Procupez show how the mutual attunement and engagement with "things" provides the conditions of possibility for becoming entangled in sexual relationships-involving both one's own body as well as others who exist at a distance. For Goodfellow it is the quest for pharmaceutical substances and the attunement to maintaining pharmaceutical relations, whereas for Precupez, it is the struggle to achieve access to permanent housing that demonstrates that it is not sex in itself, but the particular qualities of an attachment that may create or threaten life-affirming affinities. In Goodfellow's work, the distinction between caring and uncaring sex, and thus the distinction between life and death dealing relations, proves to hinge on the relations made possible by the circulation, regulation, and consumption of such things as money, pharmaceuticals, condoms, syringes, and clinical diagnostic procedures. Procupez, on the other hand, describes a case in which one woman's sensuality must be formally regulated through a set of house rules. Flirtation, attraction, and jealousy emerge and are voiced in such a way to limit sexual entanglements that might place the very life and future of a shared political project at stake. Jealousy and suspicion also figure in Das, Ellen and Leonard's description of a mother's competition for the attention of her daughter's boyfriend, where the recounting of sexual exploits in the domestic scene blurs the distinction between intimacy and incest and between care and neglect. The possibility of incest, and other "inappropriate" forms of sex always, seems to be a condition of the intimacy associated cohabitation.

When it becomes medically known that incest has occurred, Mulla describes how therapeutic address entails reevaluating the body and its position within the domestic in such a way that both might be restored as places of habitation. The restoration is affected through the scrutiny-even atomization-of the body, which in the case of 
forensic medicine takes shape by transfiguring the body into a crime scene that must be cared for in accord with the demands of obtaining and preserving the evidence necessary for building a case in a court of law. In addition, Das, Ellen, and Leonard describe how the body of the nation can be broken down into distinctive components, such that race serves as a condition of inclusion and expulsion of particular individuals into the polity. For them and for Goodfellow, the capacity to form and nurture relations turns on the institutional deployment of racial categories and permeable boundaries of carceral facilities. In addition, it is suggested that race-as it comes to be imbued with meaning by movements across institutional landscapes-gives form to the temporality, sustainability, and possibility of enacting certain forms of love, sex, and care.

In their investigations of the intimacies associated with domestic and household relations, the authors find the alliances formed between humans and non-human actors to possess crucial forms of agency, which are often read by state actors as crisis. ${ }^{5}$ By taking account of the alliances that form between human and non-human actants-such as medical forms, telephones, cars, nightgowns, pharmaceuticals, and prisons - the authors bring attention to the affects that arise within the larger assemblages that bring "things" into relation and proximity with humans. The authors do not see "things" as causative, in the sense that they alter the course of a preexistent or "naive" set of relations. Rather, "things" come to possess agency through alliances and within relations in such a way as to condition the very possibility of the intimacies investigated here. ${ }^{6}$

It becomes difficult to hold to the idea that household relations are purely constituted through shared sentiments and residence when domesticity is considered in terms of the circulation of affect. The commonalities often thought to define households and domestic relations-those assumed to lend themselves to the ready communication of emotional states, the sense of well-being and careprove contingent to the specificities of individuated experience. The articles assembled here find the intimate relations associated with domesticity to be inhabited and made possible by such things as the (ab)use of pharmaceutical technologies, jural procedures, gossip, and the meanings tied to wearing certain forms of clothing, revealing uncertainty at the core of efforts to make one's self and one's relations

Home Cultures, Vol.5, No. 3(November 2008): pg. 257-269. DOI. This article is (C) Bloomsbury Publishing and permission has been granted for this version to appear in e-Publications@Marquette. Bloomsbury Publishing does not grant permission for this article to be further copied/distributed or hosted elsewhere without the express permission from Bloomsbury Publishing. 
known. For instance, how does one narrate transfigurations in family relations when kinship is suspected, and known, to be permeated by promiscuous sexualities, incestuous unions, or the mediating influence of crack cocaine and methamphetamine?

The uncertainty surrounding efforts to make intimate arrangements known, to the self and to the world, is tied to the unbounded character of bodily expressions, forms of intimacy, and the efforts directed towards their domestication. Through such efforts as those undertaken to regulate sensuality, the domestic is revealed to be a modality through which lives and things come to be related to the home, or cultivated as suitable to the requirements of human and social life. Drawing from Das, Ellen, and Leonard, it is such "forms of doing" that imbricate intimacy with alienation, risk and danger with caring, and nurturing, criminality and vulnerability with citizenship (Das, Ellen, and Leonard, this issue). By focusing on the "fugitive emotions" (Das, Ellen, and Leonard) arising in the communications between quarreling lovers in the midst of a shared political project, an imprisoned child and his parents, an HIV discordant, and chemically dependent romantic couple, or a forensic nurse practitioner and a party injured by rape, the essays collectively show how the modalities of the domestic bring persons and things into relationship in such a way that coming together bears traces of coming apart, and obligations might be made and moved away from, but in such a way that their call (or avoidance) cannot be ignored. What falls outside the domain of "house and home" is always implicated in the domestic.

Relations must be traced and followed as they traverse and travel landscapes populated by homes, work places, schools, clinics, homeless shelters, prisons, drug treatment centers, and other sites where the effort to regulate life and death are made manifest. Each site amidst these landscapes gives rise to its own forms of rendering the domestic, for example as care or control, as text and speech, or in procedural detail. What relationships, then, might flourish, and what relations flounder, within current imaginaries of the domestic as a site of care? How is the body's future placed at stake by imagining the domestic and domestic arrangements as naive and counter-posed to such things as pharmaceutically mediated relations, political projects, the violence of the state, or the criminality of kinship? The articles in this issue are guided by these questions-in them, the sexed body 
NOT THE PUBLISHED VERSION; this is the author's final, peer-reviewed manuscript. The published version may be accessed by following the link in the citation at the bottom of the page.

emerges as multiple and generative, giving life and death to the polity, to the state, and home.

\section{Notes}

1. The relationship between the family and the political domain has a long history in Western thought, going back to at least Plato (2007) and carrying through the work of such scholars as Locke (1980), Kant (1991), Hegel (1962), Lacan (1977), Donzelot (1980), and others. For an interesting account of the history of the family within the political see Jean Bethke Elshtain (1982).

2. It is perhaps the work of Sigmund Freud that is best known for describing the intimacy between life and death and the way attitudes towards dying are folded into the intimate recesses of life granting projects, first described in Freud (1915).

3. When we discuss the operation of regulation and the state on the domestic, the type of function we have in mind might resemble Foucault's example of the onanistic child of which he spoke at length in his lectures published as Abnormal (1999). The general adoption of particular attitudes towards onanism in nineteenth-century England lead to a shift in a notion of normative parenting. This change was not affected by the passing of laws, but rather was instilled through a general pedagogical shift that redrew domestic terrain. Parents were made aware of the threat by and to their children within the home, and subsequently, materially reoriented in their ways of care. To protect the child from his own unchecked sexual desires, parents had to check sheets and clothing for signs of masturbation. This shift in notions of health, parental discipline, and standards of care results in new domestic routines, rules, and anxieties. The authors in this issue frequently examine the intersection of material and social conditions and the processes and affective shifts these intersections generate.

4. Though often used interchangeably, affect is distinct from emotion and feeling. As Teresa Brennan explains in The Transmission of Affect (2004), emotions are social, while feelings are personal and biographical. Affect, as elaborated by Brian Massumi in his introduction to Deleuze and Guattari's Thousand Plateaus (1987), is prepersonal. Massumi (2002) follows Deleuze and Guattari in characterizing affect as a body's ability to affect or be affected. In this definition, a body can be an organism, an object, or a structure. The idea of affect, therefore, is useful in constructing arguments that examine the agencies of things-a prominent feature within all of the articles.

5. Jane Bennett $(2004,2005)$ has written about non-human forms of agency and intentionality in her recent work on political action. She questions the idea that the affect associated with political decision necessarily

Home Cultures, Vol.5, No. 3(November 2008): pg. 257-269. DOI. This article is (C) Bloomsbury Publishing and permission has been granted for this version to appear in e-Publications@Marquette. Bloomsbury Publishing does not grant permission for this article to be further copied/distributed or hosted elsewhere without the express permission from Bloomsbury Publishing. 
arises from human relationships and human forms of intention. Instead, she draws from the work of Deleuze on assemblages to show how objects, or "things," can and do come together in such a way as to bring about new alliances that affect change.

6. Talal Asad has written extensively about the difference between pain as an actor upon relationships and pain as an agent within relationships (Asad 2003).

\section{References}

Asad, T. 2003. Formations of the Secular: Christianity, Islam, Modernity. Stanford, CA: Stanford University Press.

Bennett, J. 2005. "The Agency of Assemblages and the North American Blackout. Public Culture 17(3): 445-65.

Bennett, J. 2004. The Force of Things: Steps towards an Ecology of Matter." Political Theory 32(3): 347-72.

Brennan, T. 2004. The Transmission of Affect. Ithaca, New York: Cornell University Press.

Butler, Judith. 2000. Antigone's Claim: Kinship between Life and Death. New York: Columbia University Press.

Canguilhem, G. 1991. The Normal and the Pathological. New York: Zone Books

Deleuze, G. and Guattari, F. 1987. A Thousand Plateaus: Capitalism and Schizophrenia. Minneapolis: University of Minnesota Press.

Donzelot, J. 1980. The Policing of Families: Welfare versus State. London: Hutchinson.

Elshtain, J. 1982. The Family in Political Thought. Amherst, MA: University of Massachusetts Press.

Foucault, M. 1999. Abnormal: Lectures at the Collège de France, 1974-1975. New York: Picador.

Freud, S. 1915. "Attitudes towards Death." In Carrie Lee Rothgeb (ed.) The Standard Edition of the Complete Psychological Works of Sigmund Freud. Northvale, NJ: Northvale Press.

Hegel, G. W. F. 1962. Hegel's Philosophy of Right. Oxford: Clarendon Press. Locke, J. 1980. Second Treatise of Government. Indianapolis, IN: Hackett Publishing Co.

Kant, I. 1991. Metaphysics of Morals. Trans. Mary Gregor. Cambridge: Cambridge University Press

Lacan, J. 1977. Ecrits: A Selection. Trans. Alan Scheridan. New York: Norton. Massumi, Brian. 2002. Parables for the Virtual: Movement, Affect, Sensation. Durham, North Carolina: Duke University Press.

Plato. 2007. The Republic. Trans. Desmond Lee. London: Penguin Books.

Home Cultures, Vol.5, No. 3(November 2008): pg. 257-269. DOI. This article is (C) Bloomsbury Publishing and permission has been granted for this version to appear in e-Publications@Marquette. Bloomsbury Publishing does not grant permission for this article to be further copied/distributed or hosted elsewhere without the express permission from Bloomsbury Publishing. 
NOT THE PUBLISHED VERSION; this is the author's final, peer-reviewed manuscript. The published version may be accessed by following the link in the citation at the bottom of the page.

\section{About the Authors}

Aaron Goodfellow is currently employed as a Lecturer in the Department of Anthropology and as Associate Director of the Program for the Study of Women, Gender, and Sexuality at Johns Hopkins University. He has conducted extensive fieldwork with gay men in the USA who have formed families and are raising children, and on the institutional landscapes defined by biomedical efforts to intervene in the spread of HIV/AIDS and other sexually transmitted diseases.

Sameena Mulla is Assistant Professor in the Department of Social and Cultural Sciences at Marquette University where she teaches anthropology. She is currently working on a book focusing on the intertwined nature of therapeutic and juridical institutions in sexual assault interventions in Baltimore, Maryland, based on three and a half years of field research in an emergency room forensic nursing program.

Home Cultures, Vol.5, No. 3(November 2008): pg. 257-269. DOI. This article is (C) Bloomsbury Publishing and permission has been granted for this version to appear in e-Publications@Marquette. Bloomsbury Publishing does not grant permission for this article to be further copied/distributed or hosted elsewhere without the express permission from Bloomsbury Publishing. 